\title{
The Influence of Domestic Economic Factors on Inflation in Indonesia
}

\author{
Brilian Amial Rasyid ${ }^{1}$, Dede Ruslan ${ }^{2}$, Murni Daulay ${ }^{2}$ \\ ${ }^{1}$ Postgraduate Students at Faculty of Economic and Business, University of Sumatera Utara, Indonesia \\ ${ }^{2}$ Postgraduate Lecturer at Faculty of Economic and Business, University of Sumatera Utara, Indonesia \\ Corresponding Author: Brilian Amial Rasyid
}

\begin{abstract}
Inflation is a monetary and structural phenomenon in the Indonesian economy. The objective of this research is to analyse the indirect effect of Debt, Net Export and Interest Rate on the Inflation through Exchange Rate : and to analyse the direct effects of Debt, Net export, Interest Rate, and exchange rate on the inflation in Indonesia. The research uses secondary data carried out from Bank Indonesia. Statistics Center Board, DJPPR ( Directorate General of Financing and Risk Management) of the ministry of finance and from the Ministry of Trade. Quarterly data of 1995-2020 are employed as the data and analysed with path analysis technique. Inderect result shows that there is positive and significant effect of debt on inflation through exchange rate, there is positive and significant effect of net export on inflation through exchange rate, and there is positive and insignificant effect of interest rate on inflation throught exchange rate. Direct result shows that there is negative and insignificant effect of debt on inflation, there is negative and insignificant effect of net export on inflation, there is positive and significant effect of interest rate on inflation, and there is positive and significant effect of exchange rate on inflation.
\end{abstract}

Keywords: Debt, Net Exports, Interest Rates, Exchange Rates, Inflation

\section{INTRODUCTION}

Inflation according to Bank Indonesia (BI) is an increase in the prices of goods and services in general and continuously within a certain period of time. An increase in the price of one or two goods alone cannot be called inflation unless it causes an increase in other goods. Meanwhile, according to the Central Statistics Agency (BPS), an increase in the price of goods and services can result in a decrease in the value of money. So that inflation can be called a decrease in the value of money against the value of goods and services in general. According to BI, inflation determinants are caused by pressure from the demand side (demand pull inflation) and pressure from the cost side (cost push inflation). The demand factor is due to high demand exceeding availability. There is a scarcity factor or scarcity that causes the price of goods to be expensive. For example, the effects of seasonal factors such as holidays and new years cause temporary inflation in the consumption of staple goods, so the government needs market intervention by providing goods from exports or providing subsidized assistance. Meanwhile, cost push inflation can be caused by depreciation of the exchange rate or exchange rate, the impact of imported inflation, or changes in the unstable world economy.

Seeing the Indonesian economic phenomenon is very contrary to the generally accepted theory. Lower interest rates cause the rupiah to weaken. This is because the money supply becomes large. Should the rupiah exchange rate decline or weaken, then Indonesia's exported goods should be cheaper for Indonesia's export destination countries. The phenomenon of the weakening of the rupiah is more about 
the impact on export performance. The weakening of the exchange rate will also increase the cost of imports. So that exporters benefit from transactions using foreign currency. Indonesia's exports, which are dominated by the non-oil and gas sector by $90 \%$, only recorded a growth of $2.03 \%$ in 2018. So that the weakening factor of the rupiah does not necessarily encourage export performance in Indonesia. Inflation also reflects prices that have been increasing continuously and accompanied by a decrease in people's purchasing power. Then monetary policy responds by increasing the money supply. So that people have purchasing power. But the growth in the money supply does not always lead to inflation (Ofori, Danquah \& Zhang, 2017). When examined more deeply, the cause of inflation is not only caused by monetary factors. According to Perry Warjiyo (2020), the supply of commodities that remains adequate even though there is an increase in consumer demand is sufficient to contain inflation. So that the 2019-2020 inflation trend continues to decline. The end of 2019 was 2.72 percent and in the third quarter of 2020 it was 1.32 percent.

Inflation can be caused by monetary and non-monetary factors, Gunawan (1995). Inflation in Indonesia occurs not only due to short-term phenomena such as situational factors or the domino effect of crises in other countries. However, the problem of inflation in Indonesia is more of a long-term problem caused by technical and nontechnical obstacles as well as structural obstacles in managing the national economy. The different views between monetarian and neo-structuralist schools view inflation, namely the imbalance of the Money Supply (monetary sector) and on the influence of money on the economy in terms of supply and production (structuralist). In developing countries such as Indonesia, inflation is mostly caused by structural economic factors that are longterm influenced by price pushes (Cost Push Inflation) Compared to monetary factors that are influenced by Demand Pull Inflation
(Demand). And the government prefers to use a monetary approach. So that the problem of inflation in Indonesia is never finished. The monetary approach is mostly used by developed countries, not developing countries like Indonesia. There needs to be a serious effort to remove the structural barriers that cause inflation so that economic development must also pay attention to the real sector so that the Indonesian economy can achieve Steady Growth. So on that basis the authors were inspired to find solutions to help formulate the right formulation to overcome high inflation with a structuralist approach by looking for a relationship with monetary policies approach.

\section{LITERATURE REVIEW Inflation Theory}

Several literatures discuss a lot about the theory of inflation by economists who explain inflation. According to Adwin S Atmaja (1999), there are 4 theories for the causes of inflation, including:

\section{a. Quantity Theory}

This theory was put forward by Irving Fisher. The essence of this theory emphasizes two things, namely: Inflation only occurs due to the volume of money in circulation, both currency and demand deposits and inflation occurs due to an increase in the amount of money due to expectations of future price increases.

\section{b. Keynesian Model}

This theory by Keynes explains that inflation occurs due to an inflationary gap, namely the result of aggregate demand exceeding the amount of goods available (aggregate supply). This is short-term inflation. Usually, inflation will stop when people don't have purchasing power anymore.

\section{Mark-up Model}

Inflation is determined by 2 (two) components, namely the cost of production and profit margin. If there is an increase in these 2 components, there will be an 
increase in the selling price of the commodity in the market.

\section{Structuralist Model}

This theory is a structural phenomenon in developing countries. This is caused by cost push inflation. This structural phenomenon is called a structural bottleneck which occurs because of 3 things: Supply from the agricultural (food) sector is inelastic, limited foreign exchange reserves are caused by exports that are smaller than imports and government spending is limited so that the government incurs debt or prints money.

\section{Causes of Inflation}

Based on the cause, inflation is classified into two types, namely Demand Pull Inflation and Cost Push Inflation. Demand pull inflation is where there is excess demand (excess demand) for goods and services (Gunawan, 1995). inflation which usually occurs when the economy is growing rapidly. The increase in public demand for consumer goods has prompted the government and entrepreneurs to increase investment through credit. If the demand continues to increase while all production factors are fully used, this will cause an increase in prices. This continuous increase in prices will cause inflation, and inflation that is too high in turn will no longer create job opportunities, but will on the contrary lead to labor unemployment. This can be understood if rising prices are not followed by an increase in wages or salaries, such as labor with wages contracted for several years, which causes people's purchasing power to be low. If this process continues with low purchasing power, production will stop and workers will be laid off from work. Thus, many workers are unemployed.

\section{Inflation Impact}

Inflation that occurs in an economy has several impacts or consequences, namely as follows: a. Inflation can lead to a redistribution of income among community members. This will affect the economic welfare of members of society, because the income redistribution that occurs will cause one person's real income to increase, but the real income of others to fall.

b. Inflation can cause a decrease in economic efficiency (economic efficiency).

c. Inflation can cause changes in output and employment opportunities.

d. Inflation can create an unstable environment (unsable environment) for economic decisions.

The impact of inflation on individuals and society, namely:

1) Worsening of income distribution

During times of inflation, the value of fixed assets such as land or buildings increases faster than income, while lowincome people who usually do not have fixed assets will experience a decline in the value of their real income.

\section{2) Real income has fallen}

Most of the workforce has nominal income which is fixed value. In times of inflation, an increase in the price of goods will decrease people's real income.

\section{Inflation Relationship with Debt}

Debt is a debt policy that cannot be separated from the country's development process aimed at catching up with economic development. The gap between west and east infrastructure development is visible in Indonesia. So it is not surprising that there are differences in the price of goods and services between the central government and provinces in the east. So that the option to borrow money abroad is justified by prudential fund management. The main priority of using these debt funds is to reduce poverty and create job opportunities. However, debt that is too large will cause serious problems in the future if controlling the currency rate fails. According to Imamudin Yuliadi (2006), foreign debt is heavily influenced by non-economic factors. 
The exchange rate has a significant effect on inflation, while other factors have little effect. Inflation can be affected by an increase in foreign debt caused by the depreciation of the Rupiah exchange rate against the Dollar and other foreign currencies. Foreign debt in the form of foreign currency (foreign currency) if the value of the rupiah depreciates, the debt will get bigger. As a result, the balance of payments is deficit while the need for infrastructure development is mostly built with investment and money loans from other countries. Infrastructure development must be carried out to drive economic activity to continue experiencing growth.

\section{Inflation Relationship with Net Exports}

Net exports are the difference between exports minus imports. Export and import activities are based on the basis that every country needs each other and no one is truly capable of being an independent country that does not need another country. This is due to differences in characteristics, differences in natural and human resources, demographics, economic systems and climate which also cause differences in production goods in a country. In this way, countries complement each other due to effectiveness and efficiency in producing goods. Thus, it is necessary to exchange goods and services between countries in the form of trade relations to meet the needs of this activity aimed at increasing the country's foreign exchange in international trade. The definition of international trade itself is trade between or across countries, which contains exports and imports (Tambunan, 2000). Meanwhile, foreign exchange reserves are state assets / assets reflecting the strength of the country's global economy and are used for the welfare of the people. In the financing of international trade transactions using Foreign Exchange Reserves.

\section{Relationship between Interest Rates (BI Rate) and Inflation}

According to the classical interest rate theory, high interest rates can increase the volume of savings in society (Nopirin, 2000). The act of raising interest rates is due to the high money supply in society which results in inflation. The interest rate is the percentage level of the money burden that has been borrowed. This has a very important effect on investment funds for money and capital market customers. For example, when the government wants to strengthen industrial companies to be able to be competitive, the government usually offers loans to these companies at low interest rates. And when the money supply is very large in society, Bank Indonesia will try to attract this money by raising interest rates so that people are willing to invest and save in the form of deposits. The money supply in the community is controlled by Bank Indonesia using a monetary instrument with an interest rate (BI rate). This instrument has a very big influence on the Indonesian economy in controlling inflation. An increase in the BI rate will encourage an increase in interbank interest rates as well as increase lending rates. The positive impact is that BI can control the money supply which causes inflation. Meanwhile, the negative impact is that the Cost of Money becomes expensive. Market competitiveness has become sluggish. Exports are not competitive because entrepreneurs do not want to borrow bank money for business expansion tend to prefer to save funds in the form of deposits rather than spending money on business. The reduction in the BI Rate has resulted in entrepreneurs being more willing to borrow money to move into the real sector. But of course the effect is increased inflation. So in this case the government has 2 (two) options in regulating the money supply.

\section{MATERIALS \& METHODS}

The scope of this research is in Indonesia and looks at the relationship with the path analysis between variables of debt, 
net exports, interest rates / BI rate, exchange rate, and inflation rate in Indonesia. The years of observation in this study are from 2000 to 2020. This research entirely uses secondary data in the form of time series data, namely data collected during a certain period of time. Sources of research data were obtained from various literature studies including books, journals, electronic literature / websites (observer at home page). Some of the data comes from literature in the form of reports published by the World Bank, Bank Indonesia and the Central Bureau of Statistics.

\section{Statistical Analysis}

In analyzing the magnitude of the influence of independent variables on dependent variables, this study uses a structural equation, namely Path Analysis. Path Analysis is used if in theory we believe we are dealing with problems related to cause and effect. Path Analysis is assisted by the SPSS application program.

\section{RESULT}

\section{Normality Test Results}

The results of the calculation of the normality test on the unstandardized residual values in the 2 model structures will produce 2 residuals as follows:

Residual 1 (Structure 1)

\begin{tabular}{|c|c|c|}
\hline \multicolumn{3}{|c|}{ One-Sample Kolmogorov-Smirnov Test } \\
\hline & & Unstandardized Residual \\
\hline \multicolumn{2}{|l|}{$\mathrm{N}$} & 103 \\
\hline \multirow{2}{*}{$\begin{array}{l}\text { Normal } \\
\text { Parameters }\end{array}$} & Mean &, 0000000 \\
\hline & Std. Deviation & 1249,13853733 \\
\hline \multirow{3}{*}{$\begin{array}{l}\text { Most Extreme } \\
\text { Differences }\end{array}$} & Absolute & ,070 \\
\hline & Positive & ,059 \\
\hline & Negative &,- 070 \\
\hline \multicolumn{2}{|c|}{ Kolmogorov-Smirnov Z } & ,708 \\
\hline \multicolumn{2}{|c|}{ Asymp. Sig. (2-tailed) } & ,698 \\
\hline \multicolumn{3}{|c|}{ a. Test distribution is Normal. } \\
\hline \multicolumn{3}{|c|}{ b. Calculated from data. } \\
\hline
\end{tabular}

Based on the SPSS output table, the total observation data of 103 data has the Asymp.Sig value. (2-tailed) 0.698 which is greater than 0.05 . So it was concluded based on the K-S test above that the data were normally distributed. The assumption of data normality has been fulfilled
Residual 2 (Structure 2)

\begin{tabular}{|l|l|l|}
\hline \multicolumn{2}{|l|}{ One-Sample Kolmogorov-Smirnov Test } \\
\hline $\mathrm{N}$ & Unstandardized Residual \\
\hline \multirow{2}{|c|}{$\begin{array}{l}\text { Normal } \\
\text { Parameters }\end{array}$} & Mean & 103 \\
\hline \multirow{2}{*}{$\begin{array}{l}\text { Most Extreme } \\
\text { Differences }\end{array}$} & Std. Deviation &, 0000000 \\
\cline { 2 - 3 } & Absolute &, 226 \\
\cline { 2 - 3 } & Positive &, 226 \\
\cline { 2 - 3 } Negative &,- 162 \\
\hline Kolmogorov-Smirnov Z & 2,291 \\
\hline Asymp. Sig. (2-tailed) &, 0675 \\
\hline \multicolumn{2}{|l|}{ a. Test distribution is Normal. } \\
\hline
\end{tabular}

Based on the SPSS output table, the total observation data of 103 data has the Asymp.Sig value. (2-tailed) 0.0675 is greater than 0.05 . So it was concluded based on the K-S test above that the data were normally distributed. The data normality assumption has been fulfilled.

\section{Multicollinearity Test Results}

The calculation results from the multicollinearity test on the Collinearity Statistics value on the 2 Structure model are as follows:

\section{Model Structure 1}

\begin{tabular}{|l|l|l|l|}
\hline \multicolumn{2}{|l|}{ Coefficients $^{\mathbf{2}}$ Model } & Collinearity Statistics \\
\cline { 3 - 4 } \multicolumn{2}{|l|}{} & Tolerance & VIF \\
\hline \multirow{3}{*}{1} & (Constant) & & \\
\cline { 2 - 4 } & Utang &, 696 & 1,436 \\
\cline { 2 - 4 } & ekspor netto &, 903 & 1,108 \\
\cline { 2 - 4 } \multicolumn{2}{|l|}{ suku bunga } &, 760 & 1,316 \\
\hline \multicolumn{2}{|l|}{ a. Dependent Variable: kurs } & \\
\hline
\end{tabular}

The Tolerance value for the debt variable (X1) is 0.696. The net export variable $(\mathrm{X} 2)$ is 0.903 and the interest rate (X3) is 0.760 . The tolerance value for the three independent variables is greater than 0.10 . Meanwhile, the VIF value for the debt variable (X1) is 1.436. The net export variable $(\mathrm{X} 2)$ is 1.108 and the interest rate (X3) is 1.316. The VIF value of the three independent variables is less than 10.00. Then it refers to the decision making in the multicollinearity test that it is concluded that there are no multicollinearity symptoms in the regression model.

\section{Model Structure 2}

\begin{tabular}{|l|l|l|l|}
\hline \multicolumn{2}{|l|}{ Coefficients $^{\text {a }}$ Model } & Collinearity Statistics \\
\cline { 3 - 4 } \multicolumn{2}{|l|}{} & Tolerance & VIF \\
\hline \multirow{3}{*}{1} & (Constant) & & \\
\cline { 2 - 4 } & Utang &, 772 & 1,295 \\
\cline { 2 - 4 } & ekspor netto &, 988 & 1,012 \\
\cline { 2 - 4 } & suku bunga &, 948 & 1,055 \\
\cline { 2 - 4 } & Kurs &, 742 & 1,347 \\
\hline \multicolumn{2}{|l|}{ a. Dependent Variable: inflasi } \\
\hline
\end{tabular}


The Tolerance value for the debt variable $(\mathrm{X} 1)$ is 0.772 . The net export variable $(\mathrm{X} 2)$ is 0.988 . The interest rate variable $(\mathrm{X} 3)$ is 0.948 . Exchange variable (Y1) is 0.742 . The tolerance value for the four independent variables is greater than 0.10 . Meanwhile, the VIF value for the debt variable $(\mathrm{X} 1)$ is 1.295. The net export variable $(\mathrm{X} 2)$ is 1.012 . The interest rate variable $(\mathrm{X} 3)$ is 1.055 . The exchange rate variable (Y1) is 1.347. The VIF value of the four independent variables is less than 10.00. So referring to the decision making in the multicolinearity test, it is concluded that there are no multicolinearity symptoms in the regression model.

\section{Autocorrelation Test Results}

The calculation results from the Durbin Watson test on the 2 Structure model are as follows:

\section{Model Structure I}

\begin{tabular}{|l|l|l|l|l|l|}
\hline \multicolumn{5}{|l|}{ Model Summary } \\
\hline Model & R & R Square & Adjusted R Square & Std. Error of the Estimate & Durbin-Watson \\
\hline 1 &, $970^{\mathrm{a}}$ &, 940 &, 938 & 831,48248 &, 705 \\
\hline
\end{tabular}

The Durbin-Watson (d) value is 0.705 . DW numbers are between $-2<\mathrm{d}<2$. So the decision making in the Watson Durbin test is concluded that there are no problems or symptoms of autocorrelation.

\section{Model Structure II}

\begin{tabular}{|c|c|c|c|c|c|}
\hline \multicolumn{6}{|c|}{ Model Summary $^{b}$} \\
\hline Model & $\mathbf{R}$ & R Square & Adjusted R Square & Std. Error of the Estimate & Durbin-Watson \\
\hline 1 &, $869^{\mathrm{a}}$ &, 755 &, 745 & 6,0009 & 1,104 \\
\hline
\end{tabular}

The Durbin-Watson value (d) is 1.104. DW numbers are between $-2<\mathrm{d}<2$. So the decision making in the Watson Durbin test is concluded that there are no problems or symptoms of autocorrelation.

\section{Path Analysis Test Results \\ 1. Model Structure I}

\begin{tabular}{|l|l|l|l|l|l|}
\hline \multicolumn{4}{|l|}{ Model Summary } \\
\hline Model & R & R Square & Adjusted R Square & Std. Error of the Estimate & Durbin-Watson \\
\hline 1 &, $970^{\mathbf{a}}$ &, 940 &, 938 & 831,48248 &, 705 \\
\hline
\end{tabular}
a. Predictors: (Constant), interest rates, net exports, debt
b. Dependent Variable: kurs

The value or $\mathrm{R}$ square found in the Model Summary table is 0.940 , indicating that the contribution or contribution of the influence of $\mathrm{X} 1, \mathrm{X} 2, \mathrm{X} 3$ on $\mathrm{Y} 1$ is $94.0 \%$, while the remaining $6 \%$ is the contribution of other variables not included in the study. The value of e1 can be found using a formula e $1=(\sqrt{1}-0,940)=0,245$

\begin{tabular}{|c|c|c|c|c|c|c|}
\hline \multicolumn{7}{|c|}{ Coefficients $^{\mathrm{a}}$} \\
\hline \multirow{2}{*}{\multicolumn{2}{|c|}{ Model }} & \multicolumn{2}{|c|}{ Unstandardized Coefficients } & \multirow{2}{*}{$\begin{array}{l}\text { Standardized Coefficients } \\
\text { Beta }\end{array}$} & \multirow[t]{2}{*}{$\mathbf{T}$} & \multirow[t]{2}{*}{ Sig. } \\
\hline & & B & Std. Error & & & \\
\hline \multirow[t]{4}{*}{1} & (Constant) & 3794,650 & 403,640 & & 9,401 &, 000 \\
\hline & Debt & 2,465 &, 112 & ,997 & 22,083 &, 000 \\
\hline & net exports & 7,350 & 1,091 & 267 & 6,736 &, 000 \\
\hline & interest rate & 17,126 & 15,113 &, 049 & 1,133 & ,260 \\
\hline
\end{tabular}

\section{Path Coefficient Model Structure I:}

Referring to the regression output of the Structure I model in the Coefficients table, it can be seen that the significance value of the debt variable (X1) of 0.000 has a significant effect on $\mathrm{Y} 1$. The net export variable (X2) of 0.000 has a significant effect on Y1. The interest rate variable (X3) 
of 0.260 shows an insignificant effect. Based on Standardized Coefficients, namely the coefficients used in path analysis, the diagram is formed as follows:

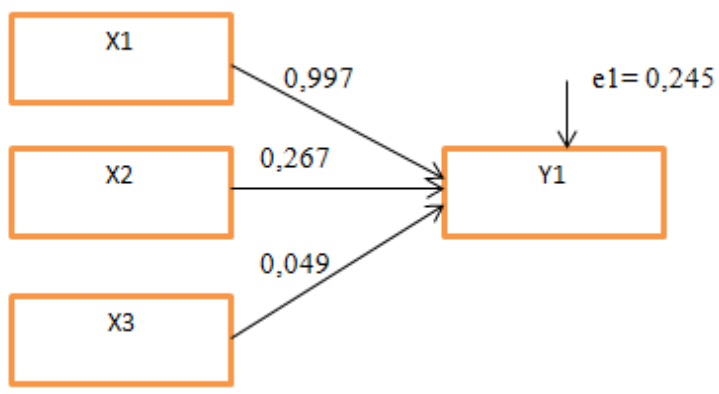

Figure 1. Diagram Model Structure I

\section{Model Structure II}

\begin{tabular}{|c|c|c|c|c|c|}
\hline \multicolumn{6}{|c|}{ Model Summary $^{b}$} \\
\hline Model & $\mathbf{R}$ & R Square & Adjusted R Square & Std. Error of the Estimate & Durbin-Watson \\
\hline 1 &, $869^{\mathrm{a}}$ &, 755 & ,745 & 6,0009 & 1,104 \\
\hline
\end{tabular}

The value or R square found in the Model Summary table is 0.755 , indicating that the contribution or contribution of the influence of $\mathrm{X} 1, \mathrm{X} 2, \mathrm{X} 3$ and $\mathrm{Y} 1$ on $\mathrm{Y} 2$ is $75.5 \%$ while the remaining $24.5 \%$ is the contribution of other variables which are not included in the study. The value of e 2 can be found using the formula e $2=(\sqrt{1}-0,755)=0,49$

\begin{tabular}{|c|c|c|c|c|c|c|}
\hline \multicolumn{7}{|c|}{ Coefficients $^{\mathrm{a}}$} \\
\hline \multirow{2}{*}{\multicolumn{2}{|c|}{ Model }} & \multicolumn{2}{|c|}{ Unstandardized Coefficients } & \multirow{2}{*}{$\begin{array}{l}\text { Standardized Coefficients } \\
\text { Beta }\end{array}$} & \multirow[t]{2}{*}{$\mathbf{T}$} & \multirow[t]{2}{*}{ Sig. } \\
\hline & & $\mathrm{B}$ & Std. Error & & & \\
\hline \multirow[t]{5}{*}{1} & (Constant) & $-8,712$ & 2,628 & & $-3,315$ & ,001 \\
\hline & Debt &,- 002 &, 001 &,- 271 & $-1,861$ &, 066 \\
\hline & net exports &,- 002 &, 006 &,- 025 &,- 392 & ,696 \\
\hline & interest rate & 1,075 &, 072 &, 862 & 14,932 & 000 \\
\hline & Exchange rate & 001 &, 000 & ,328 & 2,463 & 016 \\
\hline \multicolumn{7}{|c|}{ a. Dependent Variable: inflasi } \\
\hline
\end{tabular}

\section{Path Coefficient Model Structure II:}

Referring to the regression output of the Structure II model in the Coefficients table, it can be seen that the significance value of the debt variable (X1) of 0.066 has no significant effect on Y2. The net export variable (X2) of 0.696 has no significant effect on Y1. The interest rate variable (X3) of 0,000 shows a significant effect. And the exchange rate variable (Y2) of 0.016 shows a significant effect.

Based on Standardized Coefficients, namely the coefficients used in path analysis, the diagram is formed as follows:

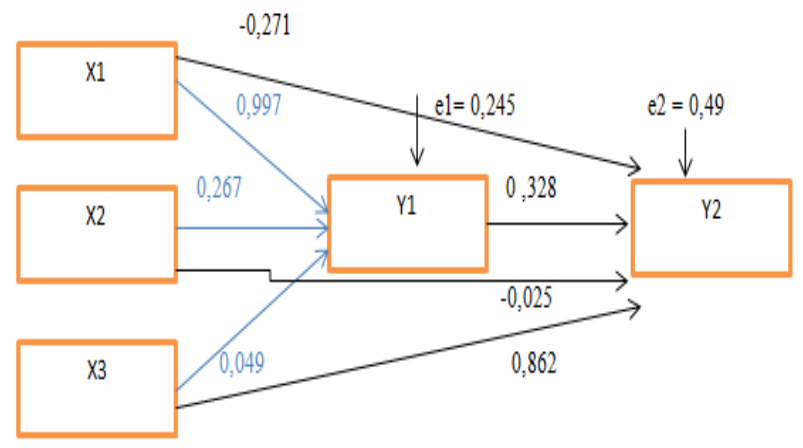

Figure 2. Diagram Model Structure II 


\section{DISCUSSION}

Based on the data normality test, it is known that all data are declared normally distributed. Based on the results of the multicollinearity test, it is known that the data is concluded that there are no multicollinearity symptoms in the regression model. Based on the autocorrelation test of decision making in the Watson Durbin test, it was concluded that there were no autocorrelation problems or symptoms.

Discussion of the results of the analysis of the contribution of the significant influence of indirect and direct variables:

\section{a. Indirect influence}

Contribution of variables is very influential above $50 \%$. Great value $R^{2}$ or

$\mathrm{R}$ square of 0.940 indicates that the contribution or contribution of the influence of $\mathrm{X} 1, \mathrm{X} 2, \mathrm{X} 3$ on $\mathrm{Y} 1$ is $94 \%$. The level of significance of each variable is as follows: variable $\mathrm{X} 1$ equal to $0,000<0,05$ (significant effect), the variable $\mathrm{X} 2$ is equal to $0,00<0,05$ (significant effect), and the $\mathrm{X} 3$ variable $0,260>0,05$. (effect is not significant).

\section{b. Direct Influence}

Contribution of variables is very influential above $50 \%$. The value of $\mathrm{R} 2$ or $\mathrm{R}$ square of 0.755 indicates that the contribution or contribution of the influence of $\mathrm{X} 1, \mathrm{X} 2, \mathrm{X} 3$ on $\mathrm{Y} 1$ is $75.5 \%$. The level of significance of each variable is as follows:

The significance value of each variable is variable $\mathrm{X} 1$ equal to $0,066<0,05$ (the effect is not significant), the variable $\mathrm{X} 2$ is equal to $0,696>0,05$ (the effect is not significant), and the $\mathrm{X} 3$ variable is equal to $0,000<0,05$ (significant effect), and the Y1 variable is equal to $0,016<0,05$ (significant effect).

\section{Analysis of positive or negative effects between variables}

a. There is a significant positive indirect debt effect on inflation through the exchange rate with the equation;

$\mathrm{Y} 2=(\mathrm{PY} 1 \mathrm{X} 1) \cdot(\mathrm{PY} 2 \mathrm{Y} 1)=$ $(0,997) \cdot(0,328)=0,327$. This result contradicts the theory that debt has a negative effect on exchange rates. The rupiah exchange rate will decrease (depreciate) if there is inflation. Because paying debts using foreign currency which is appreciated so that debt increases. In accordance with the theory of the exchange rate pass through (ERPT) mechanism, namely inflation and depreciation will be comparable. Contrary to the significant positive results of debt on inflation is previous research by Lim Chia Yen and Abdullah Muhammad Azam (2017). This is due to a deficit in the trade balance and the people's purchasing power for imported goods is very low. So that it is covered with debt to maintain purchasing power.

b. There is a significant positive effect of Net Exports indirectly on inflation through the exchange rate with the equation;

$\mathrm{Y} 2=(\mathrm{PY} 1 \mathrm{X} 2) \cdot(\mathrm{PY} 2 \mathrm{Y} 1)=(0,267) \cdot($ $0,328)=0,09$. And contrary to the theory of the exchange rate pass through (ERPT) mechanism, namely inflation and depreciation will be comparable. Inflation will boost exports. Even though net exports are safe, it is not because the productivity of the Indonesian economy has increased, but that the economy is not running. The public's consumption of imported goods has decreased drastically. This inflation is deliberately suppressed by the government by lowering interest rates. The government wants people to spend money but on the one hand their purchasing power is also low.

c. There is an indirect positive effect of interest rates on inflation through the exchange rate with the equation; 
$\mathrm{Y} 2=(\mathrm{PY} 1 \mathrm{X} 3) \cdot(\mathrm{PY} 2 \mathrm{Y} 1)=$ $(0,049) \cdot(0,328)=0,02$. This result is in accordance with previous research by Perlambang (2017) which states that the interest rate / BI rate has a significant positive effect on inflation. And according to the classical interest rate theory. The act of raising interest rates is due to the high money supply in society which results in inflation.

d. There is no significant negative effect of debt on the inflation rate.

With equality $\mathrm{Y} 2=\mathrm{PY} 2 \mathrm{X} 1=-0,271$. This result contradicts the theory that debt has a positive effect on inflation. A significant positive result of debt on inflation is previous research by Lim Chia Yen and Abdullah Muhammad Azam (2017), which explains that domestic debt and foreign debt have a strong positive effect on inflation in Malaysia. In Indonesia, the inflation rate was very low at 1.32 in the third quarter of 2020. Meanwhile, the debt figure was very high at 5756.87 in the third quarter of 2020. Based on economic theory through the Philippine Kuva, high economic growth causes high inflation. With high debt and low inflation, it reflects that the government maintains people's purchasing power by increasing debt.

e. There is no significant negative effect of net exports on the inflation rate $\mathrm{Y} 2=$ $\mathrm{PY} 2 \mathrm{X} 2=-0.025$. This result contradicts the theory that exports have a significant positive effect on inflation in the research of Jumhur et.al (2019). And contrary to the theory of the exchange rate pass through (ERPT) mechanism, namely inflation and depreciation will be comparable. This phenomenon is due to Indonesia's foreign exchange reserves reaching their highest level in the last three years. Even though net exports are safe, it is not because the productivity of the Indonesian economy has increased, but that the economy is not running. Consumption of imported goods has decreased dramatically. When the economy is normal after the pandemic, it is certain that foreign exchange reserves will decrease along with the increase in imported goods.

f. There is a significant positive effect of interest rates on the inflation rate $\mathrm{Y} 2=$ PY2X3 $=0.862$. This result is in accordance with previous research by Perlambang (2017) which states that the interest rate / BI rate has a significant positive effect on inflation. And according to the classical interest rate theory. The act of raising interest rates is due to the high money supply in society which results in inflation.

g. There is a significant positive effect of the exchange rate / exchange rate on the inflation rate. $\mathrm{Y} 2=\mathrm{PY} 2 \mathrm{Y} 1=0.328$. These results are consistent with previous research by Adrian Sutawijaya (2012) which states that the exchange rate or exchange rate has a significant positive effect on inflation. However, contrary to the theory of the exchange rate pass through (ERPT) mechanism, inflation and depreciation will be comparable. The rupiah exchange rate increases, so what happens is deflation, not inflation, which will have an impact on the increase in imported goods. Meanwhile, net exports in the last 3 years have been in a surplus condition. An indication of an abnormal rate of inflation. The government tries to maintain people's purchasing power by protecting the rupiah, but the purchasing power of imported goods is also low.

\section{CONCLUSION}

Based on the results of the analysis, conclusions can be drawn:

a. There is a significant positive indirect effect on inflation through the exchange rate. This is because the people's purchasing power for imported goods is very low. So that it is covered with debt to maintain purchasing power.

b. There is a significant positive indirect export impact on inflation through the exchange rate. Safe net exports are not 
caused by the increased productivity of the Indonesian economy, but because the economy is not running. The public's consumption of imported goods has decreased drastically. Net exports which affect foreign exchange reserves when the global economy is sluggish. This inflation is deliberately suppressed by the government by lowering interest rates. The government wants people to spend money but on the one hand their purchasing power is also low.

c. There is an indirect positive effect of interest rates on inflation through the exchange rate. The act of raising interest rates is due to the high money supply in society which results in inflation. Reasonable response by the government

d. There is an insignificant negative effect of debt on the inflation rate.

With high debt and low inflation, it reflects that the government maintains people's purchasing power by increasing debt.

e. There is a negative and insignificant effect of net exports on the inflation rate. This phenomenon is due to Indonesia's foreign exchange reserves reaching their highest level in the last three years. Even though net exports are safe, it is not because the productivity of the Indonesian economy has increased, but that the economy is not running. Consumption of imported goods has decreased dramatically

f. There is a significant positive effect of interest rates on the inflation rate. The act of raising interest rates is due to the high money supply in society which results in inflation. Reasonable response by the government. Lower interest rates aim to make people spend money not for savings. g. There is a significant positive effect of the exchange rate / exchange rate on the inflation rate. An indication of an abnormal rate of inflation. The government tries to maintain people's purchasing power by safeguarding the rupiah, but the purchasing power of imported goods is also low.

\section{Acknowledgement: None}

\section{Conflict of Interest: None}

\section{Source of Funding: None}

\section{REFERENCES}

1. Atmadja, A. S. (1999). Inflasi di Indonesia: Sumber-sumber penyebab dan pengendaliannya. Jurnal Akuntansi dan Keuangan, 1(1), 54-67.

2. Gunawan, H. A (1995). Anggaran Pemerintah dan Inflasi di Indonesia. PAN Ekonomi UI. Gramedia. Jakarta

3. Nopirin. (2000). Ekonomi Moneter, Buku II. BPFE: Yogyakarta.

4. Ofori, C. F., Danquah, B. A., \& Zhang, X. (2017). The Impact of Money Supply on Inflation, A Case of Ghana. Imperial Journal of Interdisciplinary Research, 3(1).

5. Tambunan, Tulus T.H. (2001). Perekonomian Indonesia Teori dan Temuan Empiris. Jakarta: Ghalian Indonesia

6. Yuliadi, Imamudin (2006). Analisis Hutang Luar Negeri Indonesia Pendekatan Keseimbangan Makroekonomi. Fakultas Ekonomi. Universitas Muhammadiyah Yogyakarta.

How to cite this article: Rasyid BA, Ruslan D, Daulay M. The influence of domestic economic factors on inflation in Indonesia. International Journal of Research and Review. 2021; 8(8): 577-586. DOI: https://doi.org/10.52403/ijrr. 20210877 